\title{
Zastosowanie terapii neurofeedback w poprawie wyższych funkcji słuchowych u dzieci z ośrodkowymi zaburzeniami słuchu - wyniki wstępne
}

\section{Application neurofeedback therapy for improving the higher auditory functions of children with central auditory processing disorders - preliminary results}

\author{
Rafał Milner ${ }^{1,2}$, Małgorzata Ganc ${ }^{1,2}$, Natalia Czajka ${ }^{1,2}$, Bartosz Trzaskowski ${ }^{1,2}$, \\ Anna Piotrowska ${ }^{1,2}$, Zdzisław Marek Kurkowski ${ }^{1,2}$, Krzysztof Kochanek ${ }^{1,2}$, \\ Henryk Skarżyński ${ }^{1,2}$ \\ ${ }^{1}$ Instytut Fizjologii i Patologii Słuchu, ul. Zgrupowania AK „Kampinos” 1, 01-943 Warszawa \\ ${ }^{2}$ Światowe Centrum Słuchu, ul. Mokra 17, Kajetany, 05-830 Nadarzyn
}

Adres autora: Rafał Milner, Instytut Fizjologii i Patologii Słuchu, ul. Zgrupowania AK „Kampinos” 1, 01-943 Warszawa, e-mail: r.milner@ifps.org.pl

\section{Streszczenie}

Wstęp: Ośrodkowe zaburzenia słuchu (ang. central auditory processing disorders - CAPD) to niejednorodne dysfunkcje, w których nieprawidłowej realizacji wyższych funkcji słuchowych współtowarzyszą zaburzenia procesów poznawczych. Zakładając, że u dzieci z CAPD realizacja tych procesów może mieć wpływ na analizę informacji akustycznej, poprawa funkcji poznawczych za pomocą metody jaką jest terapia Neurofeedback powinna przynieść korzystny wpływ także na przetwarzanie słuchowe.

Cel: Celem pracy była ocena wpływu terapii Neurofeedback na poprawę wyższych funkcji słuchowych i poznawczych u dzieci z CAPD.

Metoda: Badania przeprowadzono na grupie trzech dzieci z zaburzeniami wyższych funkcji słuchowych oraz procesu uwagi. W trakcie treningu Neurofeedback tłumiono wolną czynność mózgową oraz wzmacniano czynność szybką. Wpływ treningu na funkcje słuchowe i funkcje poznawcze oceniano na podstawie wyników trzech testów wyższych funkcji słuchowych oraz komputerowych testów uwagi.

Wyniki: Analiza współczynników odzwierciedlających stosunki wybranych fal mózgowych wykazała, obniżenie po treningach nadmiernie wyrażonej czynności wolnej oraz wzmocnienia zaniżonej czynności szybkiej u wszystkich trenowanych dzieci. Normalizacji relacji pomiędzy falami mózgowymi towarzyszyła poprawa wyników testów wyższych funkcji słuchowych. Lepsze wyniki po terapii odnotowano także w komputerowych testach uwagi.

Podsumowanie: Uzyskane wyniki wskazują, że trening Neurofeedback może korzystnie wpływać na poprawę przetwarzania słuchowego na wyższych piętrach układu nerwowego oraz funkcji poznawczych.

słowa kluczowe: ośrodkowe zaburzenia słuchu • wyższe funkcje słuchowe • funkcje poznawcze • terapia Neurofeedback

Abstract

Background: Central auditory processing disorders (CAPD) are a heterogeneous dysfunctions in which incorrect execution of the higher auditory functions comorbid with disturbances of cognitive processes. Assuming that in children with CAPD the impairments of cognitive functions may have adverse impact on the acoustic information analyses, improving cognitive functions by Neurofeedback therapy should bring a positive impact also on the auditory processing.

Aim: The aim of the work was to assess the effect of Neurofeedback therapy on improving the auditory functions in CAPD children. 
Method: The study was conducted on a group of three children with CAPD and coexisting attention impairments. During the Neurofeedback training simultaneously with the slow brain activity attenuation the fast brain activity was enhanced. The impact of the training on the auditory and cognitive functions were assessed by using higher auditory functions test and computerized tests of attention performance - TAP.

Results: Analysis of coefficients represent selected brainwaves relationships showed reduction excessively expressed slow brain activity and enhancement weakly expressed fast brain activity after Neurofeedback training in all CAPD children. The normalization of relationship between individual brainwaves corresponded improvements of the results of higher auditory functions tests After therapy the improvement of TAP results has been also reported.

Conclusions: The obtained results suggest that Neurofeedback training can improve the auditory information processing at the higher levels of CNS and cognitive performance.

key words: auditory processing disorders $\bullet$ higher auditory functions $\bullet$ cognitive performance $\bullet$ Neurofeedback therapy

\section{Wstęp}

Ośrodkowe zaburzenia słuchu (ang. central auditory processing disorders - CAPD) to dysfunkcje charakteryzujące się niemożnością pełnego wykorzystania sygnału akustycznego przy jego prawidłowym odbiorze w strukturach obwodowych. Za ich przyczynę uważa się, przede wszystkim nieprawidłową realizację tzw. wyższych funkcji słuchowych. Są nimi procesy takie jak: zdolność do lokalizacji źródła dźwięku, umiejętność dyskryminacji dźwięków o różnej częstotliwości, zdolność do rozpoznawania wzorców dźwiękowych różniących się częstotliwością lub głośnością, umiejętność różnicowania i klasyfikowania dźwięków o różnym czasie trwania i ich czasowej integracji, zdolność do rozpoznawania bodźców akustycznych w obecności sygnałów zakłócających czy też detekcji sygnałów zdegradowanych (np. przefiltrowanych) [ASHA 1996]. Pomimo, iż w CAPD dominującym objawem jest nieprawidłowe przetwarzanie informacji akustycznej, ośrodkowe zaburzenia słuchu nie są jednorodną grupą dysfunkcji i nie ograniczają sie wyłącznie do problemów związanych ze słyszeniem. Pacjenci z CAPD to bardzo często osoby, u których równocześnie diagnozuje się: dysleksję, specyficzne trudności w uczeniu się czy też opóźniony rozwój mowy. Ośrodkowe zaburzenia słuchu bardzo często współwystępują też z zespołem nadpobudliwości psychoruchowej (ang. Attention Deficit Hyperactivity Disorder - ADHD). Uważa się więc, że w powstawaniu CAPD istotną rolę odgrywać mogą także, nieprawidłowo realizowane funkcje poznawcze na przykład: uwaga, pamięć operacyjna czy też funkcje językowe [Medwetsky 2009; Musiek, Chermak 2007]. Związek pomiędzy tymi funkcjami a ośrodkowymi zaburzeniami słuchu jest jednak wciąż niejasny i mało poznany.

Wielokrotnie udowodniono, że z powodu szerokiego spektrum objawów, które charakteryzują CAPD, zaburzenia te często wpływają bardzo negatywnie na wiele sfer funkcjonowania dzieci, które ich doświadczają. Są one bardzo często przyczyną trudności szkolnych, problemów z komunikowaniem się, jak również znacznie zaburzają relacje społeczne [ASHA 2005]. Pomimo skali problemu brak jest nadal w pełni skutecznych metod terapii zaburzeń ośrodkowych. $\mathrm{Na}$ chwilę obecną pomoc terapeutyczna dzieciom z CAPD ogranicza się przede wszystkim do trzech głównych aspektów: możliwie jak najskuteczniejszej poprawie środowiska akustycznego, w którym funkcjonuje dziecko, nauce różnego rodzaju technik kompensacyjnych umożliwiających przezwyciężenie istniejących trudności oraz na bezpośredniej interwencji terapeutycznej. Ta ostatnia obejmuje przede wszystkim usprawnianie zaburzonych wyższych funkcji słuchowych, a realizowana jest $\mathrm{z}$ reguły za pomocą różnego rodzaju treningów słuchowych [Ferre 2006]. W ostatnich latach zwraca się jednak coraz częściej uwagę na fakt poprawy zaburzonych w CAPD funkcji poznawczych. Podkreśla się by, działań terapeutycznych, nie ograniczać wyłącznie treningów słuchowych lecz usprawniać funkcje takie jak uwaga czy pamięć operacyjna. Poprawa ich realizacji w wyżej zhierarchizowanych ośrodkach mózgowych poprzez oddziaływania góra-dół (tzw. ang. top-down), powinna bowiem korzystnie wpływać na opracowywanie informacji akustycznej w znajdujących się niżej strukturach [Fere 2006; Masquelier 2003].

Metodą terapeutyczną, która od kilkudziesięciu lat wykorzystywana jest w terapii i rehabilitacji różnego rodzaju dysfunkcji i zaburzeń poznawczych, w tym w procesów uwagowych i pamięciowych, jest technika Neurofeedback [Coben, Evans 2011]. Dzięki zastosowaniu tzw. biologicznego sprzężenia zwrotnego (ang. biofeedback) metoda ta pozwala na normalizację określonych parametrów związanych z pracą mózgu. Parametrami tymi mogą być na przykład: amplituda, moc lub wartości współczynników opisujących relacje różnych fal mózgowych. Są one obliczane na bieżąco (online) z rejestrowanego sygnału bioelektrycznego mózgu a informacja o ich stanie prezentowana jest osobie uczestniczącej w treningu w atrakcyjnej formie (np. odtwarzanej muzyki lub gry wideo). Gra wideo lub muzyka zaprogramowane są tak, iż zmieniają się dynamicznie $\mathrm{w}$ zależności od poziomu monitorowanego parametru. W cyklu treningów osoba trenowana, „obserwując" niejako funkcjonowanie swojego mózgu, jest w stanie wiec nauczyć się zmieniać jego aktywację we właściwym kierunku. Po pewnym czasie uczy się ona również kojarzyć pożądany wzorzec aktywacji swojego mózgu z odczuwanym aktualnie „stanem mentalnym”. Osiągając ten stan wielokrotnie utrwala właściwy wzorzec aktywacji, umie go szybko przywołać a w konsekwencji szybko zmienić swoje funkcjonowanie behawioralne. Jak wspomniano powyżej, opisana zasada wykorzystywana jest w terapii zaburzeń uwagi i pamięci. Wielokrotnie udowodniono, iż problemy tego typu mogą być scharakteryzowane na podstawie pewnych specyficznych zmian w aktywacji mózgu. Wiążą się z nieprawidłowo funkcjonującymi jego rejonami i strukturami [Kropotov 2009]. Przeprowadzone badania pokazują, że normalizując ich działanie za pomocą biologicznego sprzężenia zwrotnego, metoda Neurofeedback z bardzo dobrym skutkiem może być zastosowana 
w poprawie funkcjonowania różnych aspektów uwagi czy pamięci operacyjnej [Gruzelier i wsp. 2006].

Biorąc pod uwagę fakty opisane powyżej takie jak to, że analiza odbieranej informacji dźwiękowej u dzieci z CAPD może zależeć od właściwie funkcjonującej uwagi i pamięci roboczej wydaje się, że metoda Neruofeedback może być więc także bardzo pomocna w terapii ośrodkowych zaburzeń słuchu. Nakierowana na poprawę funkcji poznawczych powinna bowiem wywrzeć korzystny wpływ także na przetwarzanie słuchowe.

\section{Materiał i metoda}

W prezentowanej pracy przedstawiono wstępne wyniki badań, które rozpoczynają serię doświadczeń mający na celu ocenę wpływu terapii Neurofeedback na poprawę wyższych funkcji słuchowych.

Praca zawiera wyniki trójki dzieci (2 chłopców i 1 dziewczynki) w wieku odpowiednio: 8, 10 i 9 lat, które poddano treningom $\mathrm{z}$ wykorzystaniem metody Neurofeedback. U wszystkich dzieci które poddano terapii stwierdzono zaburzenia wyższych funkcji słuchowych. Oprócz deficytów słuchowych, każde z dzieci wykazywało współistniejące z tymi deficytami zaburzenia koncentracji uwagi i/lub pamięci operacyjnej. Pozostałe funkcje poznawcze oraz intelekt poddanych terapii dzieci mieściły się w normie wiekowej. U żadnego z dzieci nie stwierdzono również problemów neurologicznych lub psychiatrycznych. Przed rozpoczęciem terapii i badań rodzice lub opiekunowie wszystkich dzieci podpisywali świadomą zgodę na udział dziecka w testach i treningach. Wszystkie z wykonywanych badań oraz procedury terapeutyczne uzyskały zgodę Komisji Bioetycznej przy Instytucie Fizjologii i Patologii Słuchu.

Kwalifikacja do treningów każdego z dzieci opierała się na podstawie wyników badań słuchu oraz funkcji poznawczych. Badania rozpoczynano od wizyty lekarskiej w trakcie której wykonywano badanie otoskopowe oraz przeprowadzano szczegółowy wywiad medyczny. Dzieci miały wykonane badanie audiometrii tonalnej, audiometrii impedancyjnej, badanie otoemisji akustycznych oraz badanie potencjałów wywołanych pnia mózgu (ang. auditory brain response - $A B R$ ). Wyniki wymienionych badań pozwalały dokonać oceny słuchu obwodowego.

\section{Testy wyższych funkcji słuchowych}

Podstawowym badaniem diagnostycznym były testy wyższych funkcji słuchowych. Ich wynik stanowił kluczowe kryterium kwalifikacji do terapii. Porównanie wyników testów ośrodkowych przed i po terapii pozwalało również ocenić wpływ treningów Neurofeedback na realizację wyższych funkcji słuchowych.

Każde dziecko badane było z pomocą 3 testów: testu oceny wzorców częstotliwości (ang. frequency pattern test $F P T$ ), testu oceny wzorców długości (ang. duration pattern test - DPT) oraz cyfrowym testem rozdzielnousznego słyszenia (ang. dichotic digits test - DDT).

Test oceny wzorców częstotliwości polegał na prezentacji badanemu dziecku 40 sekwencji złożonych z wysokich
$(1122 \mathrm{~Hz})$ oraz niskich $(880 \mathrm{~Hz})$ tonów. W każdej sekwencji znajdowały się zawsze trzy tony. Możliwa była zatem jedna $\mathrm{z}$ następujących sześciu, różnych kombinacji sekwencji tonów: WWN, WNW, WNN, NWN, NWW i NNW. Zadaniem badanego dziecka jest werbalne powtórzenie lub jeśli to możliwe próba odtworzenia słyszanych sekwencji (np. wysoki-wysoki-niski). Całość testu trwała ok. $10 \mathrm{~min}$. Wynik testu stanowił procent poprawnie odtworzonych sekwencji ze wszystkich prób.

Kolejnym z wykonywanych testów był test oceny wzorców długości (ang. duration pattern test - DPT). Test ten był bardzo podobny do testu oceny wzorców częstotliwości, w teście tym sekwencje tonów o różnej częstotliwości, zastąpione zostały jednak sekwencjami tonów o różnym czasie trwania: bodźcem o czasie trwania $500 \mathrm{~ms}$ (ton $\mathrm{d}$ tu$g i-D$ ) oraz bodźcem o czasie trwania $250 \mathrm{~ms}$ (ton krót$k i-K)$. Prezentowane sekwencje składały się również z 3 bodźców, które mogły tworzyć następujące kombinacje: DDK, DKD, DKK, KDK, KDD i KKD. Dzieciom prezentowano również 40 , podawanych w przypadkowej kolejności sekwencji. Tak jak poprzednio, usłyszane sekwencje po każdej próbie trzeba było odtworzyć werbalnie (np. długi-długi-krótki). Cały testu wynosił również ok. $10 \mathrm{~min}$.

Cyfrowy test rozdzielno-usznego słyszenia to kolejny z testów który wykonywano. Test ten składał się z 20 prób w trakcie których dzieciom do każdego ucha jednocześnie prezentowano dwie rożne cyfry. Cyfry zawierały się w zakresie 1-10. Zadaniem dziecka było powtórzenie wszystkich usłyszanych cyfr (również tych których dziecko nie było pewne). Wynik obliczany był oddzielnie dla lewego i prawego ucha. Stanowił on procent poprawnie podanych odpowiedzi. Czas trwania testu wynosił ok. 8-10 min.

\section{Komputerowe Testy Uwagi (ang. Tests of Attention Performance - TAP)}

Funkcjonowanie uwagi i pamięci operacyjnej oceniano na podstawie wyników prób zawartych w komputerowej baterii testów - TAP (ang. Test of Attentional Performance). Wykorzystano $6 \mathrm{z} 13$ dostępnych w pakiecie prób. Były nimi następujące próby: Alertness, Crossmodal Integration, Divided Attention, Flexibillity, Go-Nogo i Working Memory. Każdy $\mathrm{z}$ testów badał różne aspekty funkcjonowania poznawczego. Na podstawie wykonanych testów można było ocenić stan funkcjonowania aspektów uwagi takich jak jej: podzielność, przerzutność czy selektywność. Testy umożliwiały również ocenę czujności, integracji słuchowo-wzrokowej oraz pamięci operacyjnej. Dokładny opis poszczególnych testów można znaleźć w podręczniku użytkownika oraz na stronie producenta programu (www.psytest.net) [Zimmermann, Fimm 1997]. Dzieci wykonywały wszystkie z testów zarówno przed jak i po zakończeniu terapii. Podobnie jak testy wyższych funkcji słuchowych pozwalały one kwalifikować do treningów jak również ocenić zmiany funkcjonowania różnych procesów uwagowych po zakończeniu terapii.

\section{Badania psychologiczno-pedagogiczne}

Dzieci, dobierane do treningu, poddawano również badaniom psychologiczno -pedagogicznym. Przeprowadzono następujące testy: test Ravena, test pamięci wzrokowej Bentona, test sortowania kart z Wisconsin, próby czytania 
i pisania. Na ich podstawie ocenić można było, że stan funkcji poznawczych badanych dzieci, innych niż uwaga i pamięć operacyjna, jak również poziom inteligencji poddawanych terapii dzieci.

\section{Ilościowa analiza EEG (ang. quantitative electro- encephalography - QEEG)}

Po serii testów diagnostycznych na podstawie których dokonano kwalifikacji do terapii, u każdego z dzieci wykonywano ilościowe badanie EEG - (ang. quantitative electroencephalography - QEEG). Polegało ono na rejestracji sygnału bioelektrycznego mózgu, który następnie poddawano analizie ilościowej. Sygnał rejestrowano za pomocą 19-kanałowego aparatu EEG firmy Mitsar. Do rejestracji użyto również specjalnego czepka EEG wyposażonego w odpowiadającą liczbie kanałów ilość elektrod. Po założeniu czepka były one rozmieszczone na głowie badanego dziecka zgodnie z Międzynarodowym Standardem 10-20 [Jasper, 1958]. Elektrodę referencyjną stanowiły połączone razem elektrody uszne. Elektrodą uziemiającą była zamocowana w czepku dodatkowa elektroda znajdująca się w punkcie FCz. Przed każdą rejestracją dokonywano pomiaru oporności wszystkich elektrod pomiarowych. Wartości oporów nie były nigdy wyższe niż $5 \mathrm{k} \Omega$.

Badanie QEEG składało się z dwóch 3-mintowych, przeprowadzanych w losowy sposób bloków rejestracji. W trakcie każdego z nich dzieci siedziały w wygodnym i rozkładanym do pozycji półleżącej fotelu. W bloku I rejestrację przeprowadzano gdy dzieci fiksowały swój wzrok na jednym znajdującym się przed nimi i wybranym przez siebie punkcie (ang. eyes open condition - EO). W bloku II sygnał EEG był rejestrowany gdy dzieci siedząc relaksowały się mając zamknięte oczy (ang. eyes closed condition - EC).

Zarejestrowane w trakcie badań sygnały EEG przed właściwą analizą oczyszczano $\mathrm{z}$ pojawiających się $\mathrm{w}$ trakcie rejestracji artefaktów takich jak: ruchy oczu czy też artefaktów pochodzenia mięśniowego. Do usunięcia artefaktów ocznych wykorzystywano analizę składowych niezależnych ICA. Oczyszczone i odpowiednio przygotowane sygnały poddawano następnie analizie ilościowej. Dla sygnałów z poszczególnych kanałów przeprowadzano szybką analizę Fouriera i obliczano widma amplitudy względnej, bezwzględnej oraz moc sygnału w wybranych pasmach częstotliwości. Zakresy analizowanych pasm zawierały się w następujących przedziałach: Delta (1-4 Hz), Theta (4-8 Hz), Alfa (8-12 Hz), SMR (ang. sensory motor rythm) $(12-15 \mathrm{~Hz})$, Beta1 (15-20 Hz), Beta2 (20-34 Hz). Wyliczone wartości amplitudy sygnału posłużyły następnie do obliczenia wzajemnych proporcji (współczynników) poszczególnych zakresów fal w stosunku do siebie. Na podstawie uzyskanych wartości wyznaczane były również mapy rozkładu (2D) wybranych pasm częstotliwości oraz obliczane współczynniki, które mapowano następnie na powierzchnię głowy.
Uzyskane wyniki z analizy ilościowej porównywano z wynikami identycznych analiz na sygnałach zarejestrowanych w podobnych warunkach doświadczalnych znajdujących się w bazie normatywnej Human Brain Institut ${ }^{1}$ [Kropotov, 2009]. Porównania te pozwalały opisać u każdego $\mathrm{z}$ badanych dzieci ekspresję fal mózgowych o różnych częstotliwościach, zarówno w obrębie całego mózgu jak i wybranych rejonach głowy. $\mathrm{Na}$ ich podstawie opracowywano także protokoły terapii Nerurofeedback zastosowane u każdego z dzieci. Analizy ilościowe przeprowadzone na sygnałach EEG zarejestrowanych przed i po zakończeniu terapii wykorzystano także do oceny zmian ekspresji poszczególnych zakresów fal mózgowych po zakończeniu terapii.

\section{Trening Neurofeedback}

Terapia Neurofeedback przeprowadzona u każdego z trójki dzieci realizowana była w formie 40 treningowych sesji. Pojedyncza sesja terapeutyczna trwała około 1 godziny. Sesje odbywały się w miarę możliwości regularnie dwa razy w tygodniu. $\mathrm{U}$ dwójki dzieci przez cały okres terapii zastosowano ten sam protokół treningowy. Polegał on na wytłumianiu wolnej czynności bioelektrycznej mózgu (3-10 Hz) (trening fal z zakresu Delta, Theta i niska Alfa) oraz wzmacnianiu czynności szybkiej z zakresu (15-17 $\mathrm{Hz}$ ) (część zakresu fal w paśmie Beta 1) oraz (12-15 Hz) (zakres fal SMR). Tłumienie czynności wolnej odbywało się we wszystkich punktach pasa centralnego. W pasie centralnym wzmacniano również czynność szybką. Ponieważ każda $\mathrm{z}$ półkul mózgowych funkcjonuje $\mathrm{w}$ innym zakresie częstotliwości oraz z racji wyników uzyskanych w analizie ilościowej QEEG fale z zakresu 15-17 Hz były wzmacniane wyłącznie w punkcie pasa centralnego znajdującym się nad lewą półkulą mózgu. Z kolei w punkcie środkowym pasa centralnego oraz punkcie znajdującym się nad prawą półkulą tegoż pasa wzmacniano fale z zakresu $12-15 \mathrm{~Hz}$. U każdego dziecka w trakcie trwania treningów, co 10 sesji, wykonywano dodatkowe badania QEEG. Pozwalały one ewentualnie zmodyfikować zaprojektowany protokół treningu, tak by jak najlepiej zrealizować jego cele. W związku z powyższym u jednego $\mathrm{z}$ dzieci $\mathrm{w}$ trakcie trwania terapii zmodyfikowano protokół treningowy. Po 20 sesjach terapeutycznych trening w punkcie środkowym pasa centralnego zmieniono na trening w punkcie znajdującym się nad lewą okolicą czołową. W punkcie tym hamowano fale wolne $\mathrm{z}$ zakresu $3-10 \mathrm{~Hz}$ i wzmacniano fale szybkie w zakresie poszerzonym do pasma Beta1 (15-19 Hz).

\section{Wyniki}

Jak wspomniano powyżej do terapii Neurofeedback kwalifikowano dzieci z prawidłową czułością słuchu, posiadające dysfunkcje w zakresie wyższych funkcji słuchowych oraz problemy z koncentracją uwagi i/lub pamięcią operacyjną. W Tabeli 1 przedstawiono wyniki badań

\footnotetext{
1. Baza normatywna Human Brain Institute - baza zawierająca 19-kanałowe zapisy EEG wykonane u osób zdrowych: 300 dzieci w wieku 7-17 lat, 500 dorosłych w wieku 18-60 lat oraz 200 seniorów w wieku >61 lat na których wykonane mogą być różnego rodzaju analizy ilościowe QEEG. Zapisy sygnałów EEG zawarte w bazie przeprowadzono w warunkach spoczynkowych przy oczach otwartych (minimum 3 min. zapis) oraz przy oczach zamkniętych (minimum 3 min. zapis) oraz podczas wykonywania przez osoby badane 5 różnych zadań poznawczych: Go-Nogo, zadania matematycznego, próby czytania, zadania słuchowego polegającego na rozpoznawaniu długości dźwięków oraz słuchowego zadania odd-ball.
} 
Tabela 1. Wartości progów słyszenia dla poszczególnych częstotliwości uzyskane w badaniu audiometrii tonalnej oraz wyniki audiometrii impedancyjnej i otoemisji akustycznych uzyskane u każdego z dzieci

\begin{tabular}{|c|c|c|c|c|c|c|c|}
\hline & & \multicolumn{2}{|c|}{ DZIECKO I } & \multicolumn{2}{|c|}{ DZIECKO II } & \multicolumn{2}{|c|}{ DZIECKO III } \\
\hline & & $\begin{array}{c}\text { ucho lewe } \\
\text { [dB HL] }\end{array}$ & $\begin{array}{c}\text { ucho prawe } \\
\text { [dB HL] }\end{array}$ & $\begin{array}{c}\text { ucho lewe } \\
\text { [dB HL] }\end{array}$ & $\begin{array}{c}\text { ucho prawe } \\
\text { [dB HL] }\end{array}$ & $\begin{array}{c}\text { ucho lewe } \\
\text { [dB HL] }\end{array}$ & $\begin{array}{l}\text { ucho prawe } \\
\text { [dB HL] }\end{array}$ \\
\hline \multicolumn{8}{|l|}{ Audiogram częstotliwość } \\
\hline & $125 \mathrm{~Hz}$ & 15 & 15 & 20 & 20 & 20 & 25 \\
\hline & $250 \mathrm{~Hz}$ & 10 & 15 & 20 & 20 & 15 & 20 \\
\hline & $500 \mathrm{~Hz}$ & 10 & 10 & 15 & 15 & 10 & 10 \\
\hline & $1000 \mathrm{~Hz}$ & 5 & 5 & 5 & 10 & 5 & 5 \\
\hline & $2000 \mathrm{~Hz}$ & 5 & 5 & 5 & 5 & 5 & 5 \\
\hline & $4000 \mathrm{~Hz}$ & 5 & 10 & 15 & 5 & 15 & 10 \\
\hline & $8000 \mathrm{~Hz}$ & 10 & 5 & 15 & 10 & 15 & 5 \\
\hline Tympanogram (typ) & & $A$ & $A$ & $A$ & $A$ & $A$ & $A$ \\
\hline Otoemisja & & obecna & obecna & obecna & obecna & obecna & obecna \\
\hline
\end{tabular}

audiometrycznych (audiometrii tonalnej, impedancyjnej oraz otoemisji akustycznych) uzyskane przez każde $\mathrm{z}$ dzieci zakwalifikowanych do terapii.

Tabele 2-5 zawierają natomiast wyniki tych samych dzieci uzyskane w testach wyższych funkcji słuchowych oraz komputerowych testach uwagi - TAP, również przed rozpoczęciem terapii. Przy wynikach testów słuchowych umieszczono wartości normatywne natomiast w tabeli zawierającej wyniki testów uwagi wartości percentyla, w którym lokował się wynik uzyskany przez dziecko $\mathrm{w}$ danym teście.

Rycina 1 przedstawia z kolei widma amplitudy różnicowej powstałe z porównania widm sygnałów obliczonych dla sygnałów zarejestrowanych z 19 kanałów u jednego z zakwalifikowanych do terapii dzieci (DZIECKO I) w warunkach eyes-open condition (blok I) z widmami sygnałów zarejestrowanych w podobnych warunkach eksperymentalnych, zawartych w bazie normatywnej HBI. W Tabeli 6 umieszczono wartości amplitudy różnicowej oraz istotność statystyczną przeprowadzonych porównań.

Wynika z nich, że podstawowym efektem widocznym u DZIECKA I przed rozpoczęciem terapii była zawyżona wolna czynność bioelektryczna mózgu. Z wykresów widm na Rycinie 1 oraz z Tabeli 6 wynika, że zwiększona ekspresja fal wolnych dotyczyła przede wszystkim pasma Alfa $(8-12 \mathrm{~Hz})$. Była ona najsilniej wyrażona w okolicach centralno-ciemieniowych. Ponadto, rozkład przestrzenny wartości p dla amplitudy różnicowej w rozdziale na poszczególne pasma częstotliwości, umieszczony poniżej widm oraz Tabeli 6 pokazują, że oprócz fal Alfa u DZIECKA I zawyżone były również fale wolne w paśmie Delta $(2-4 \mathrm{~Hz})$ oraz Theta $(4-8 \mathrm{~Hz})$. Efekt ten był widoczny najbardziej w okolicach czołowych i ciemieniowo-potylicznych. Nadmiernej ekspresji czynności wolnej towarzyszyła zaniżona czynność szybka. Dotyczyło to wszystkich fal szybkich: SMR (12-15 Hz), Beta1 (15-20 Hz) oraz Beta2 $(20-34 \mathrm{~Hz})$ a efekt ten był najbardziej zaznaczony w okolicach czołowych. Podobne wyniki jak przedstawiono powyżej u DZIECKA I zaobserwowano także u pozostałej dwójki dzieci.

W prezentowanej pracy podstawowym celem była ocena efektów zastosowanej terapii Neurofeedback. Efekty te oceniano na podstawie kilku parametrów. Jednym z nich były współczynniki odzwierciedlające wzajemne relacje poszczególnych fal mózgowych. Tabela 7 zawiera zestawienie wartości wszystkich współczynników opisujących relacje fal wolnych i szybkich uzyskane przed rozpoczęciem terapii i po jej zakończeniu. W kolumnach prezentujących wartości współczynników po terapii czcionką pogrujbioną oznaczono te wartości, które uległy zmianie korzystnej z punktu widzenia celów prowadzonej terapii.

Jak widać u każdego z dzieci zmniejszeniu uległy współczynniki takie jak Delta/SMR, Delta/Beta1, Delta/Beta2, Theta/SMR, Theta/Beta1 oraz Alfa/Beta1. U dwojga dzieci zmniejszył się również współczynnik Theta/Beta2. U żadnego $\mathrm{z}$ dzieci po terapii nie odnotowano natomiast zmniejszenia współczynnika Alfa/Beta1 oraz Alfa/Beta2. Współczynnik te wzrastały po terapii.

Zmiany ekspresji fal mózgowych oceniano także analizując udział procentowy poszczególnych pasm częstotliwości w sygnale EEG. Tabela 4 zawiera zestawienie wartości procentowych wszystkich zakresów fal przed i po zakończeniu terapii. Wynika $\mathrm{z}$ niej, że udział procentowy fal Delta zmalał po terapii u wszystkich trenowanych dzieci. U dwójki dzieci zanotowano dodatkowo również obniżenie fal z zakresu Theta a u jednego dziecka również fal Alfa. Jednocześnie ze zmniejszaniem się ekspresji fal wolnych u wszystkich dzieci odnotowano także wzrost fal Beta1. U dwojga dzieci po terapii zwiększyła się również ekspresja fal w paśmie Beta2, a u jednego dziecka również fal SMR.

Oprócz analizy parametrów ilościowych u wszystkich badanych dzieci oceniano również zmiany funkcjonowania 
Tabela 2. Zestawienie wyników uzyskanych przed i po terapii Neurofeedback w zastosowanych testach uwagi i pamięci operacyjnej - TAP

\begin{tabular}{|c|c|c|c|c|c|c|}
\hline & \multicolumn{2}{|c|}{ DZIECKO I } & \multicolumn{2}{|c|}{ DZIECKO II } & \multicolumn{2}{|c|}{ DZIECKO III } \\
\hline & przed terapią & po terapii & przed terapią & po terapii & przed terapią & po terapii \\
\hline \multicolumn{7}{|l|}{ Alertness } \\
\hline mediana $\mathrm{RT}^{\star}$ - bez sygnału & $346(21)$ & 337 & $291(38)$ & 328 & $285(58)$ & 342 \\
\hline $\mathrm{SD}^{* *} \mathrm{RT}$ - bez sygnału & $179(2)$ & 182 & $54(54)$ & 54 & $99(21)$ & 130 \\
\hline mediana RT - z sygnałem & $340(14)$ & 260 & $287(18)$ & 297 & $268(38)$ & 355 \\
\hline SD RT - z sygnałem & $146(12)$ & 49 & $54(62)$ & 55 & $51(73)$ & 78 \\
\hline indeks fazowy & $0,02(16)$ & 0,25 & $0,01(18)$ & 0,09 & $0,06(34)$ & $-0,03$ \\
\hline \multicolumn{7}{|l|}{ Working Memory } \\
\hline liczba błędów & 34 & 0 & 0 & 0 & 1 & 0 \\
\hline liczba ominięć & 8 & 7 & 2 & 0 & 2 & 1 \\
\hline \multicolumn{7}{|l|}{ Flexibility } \\
\hline mediana RT & 900 & 740 & $910(2)$ & 707 & 728 & 764 \\
\hline SD RT & 287 & 202 & $159(14)$ & 146 & 172 & 144 \\
\hline liczba błędów & 3 & 1 & 0 & 0 & 1 & 3 \\
\hline \multicolumn{7}{|l|}{ Divided Attention } \\
\hline liczba błędów całkowita & $10(3)$ & 2 & $2(50)$ & 4 & $4(16)$ & 2 \\
\hline liczba ominięć słuchowych & 4 & 3 & 6 & 4 & 0 & 0 \\
\hline liczba ominięć wzrokowych & 9 & 6 & 3 & 1 & 4 & 4 \\
\hline liczba ominięć całkowita & $13(4)$ & 9 & $9(12)$ & 5 & $4(36)$ & 4 \\
\hline \multicolumn{7}{|l|}{ Go-NoGo } \\
\hline mediana RT & 234 & 177 & 161 & 119 & 52 & 96 \\
\hline SD RT & 704 & 705 & 469 & 525 & 279 & 330 \\
\hline liczba błędów & $5(4)$ & 4 & $9(4)$ & 0 & $11(3)$ & 8 \\
\hline \multicolumn{7}{|l|}{ Cross-modal Integration } \\
\hline liczba błędów & 1 & 4 & 0 & 0 & 3 & 0 \\
\hline liczba ominięć & 1 & 2 & 0 & 0 & 2 & 1 \\
\hline
\end{tabular}

Czcionką pogrubioną oznaczono wyniki, które uległy zmianom korzystnym z punktu widzenia zastosowanej terapii. Kursywą oznaczono parametry, które zmieniły się niekorzystnie po terapii. W nawiasach przy wartościach parametrów z prób wykonanych przed terapią umieszczono wartości percentyla, w którym lokował się wynik każdego z dzieci.

${ }^{*} \mathrm{RT}$ (ang. re action time) - czas reakcji; ${ }^{* *}$ SD (ang. standard deviation) - odchylenie standardowe.

Tabela 3. Wyniki testu różnicowania wzorców częstotliwości (ang. frequency pattern test - FPT) uzyskane u każdego z dzieci przed rozpoczęciem terapii Neurofeedback oraz po jej zakończeniu. W tabeli umieszczono również procentową wartość zmiany wyniku po zakończeniu terapii

\begin{tabular}{cccc}
\hline FPT & Przed terapią & Po terapi & \% zmiany \\
\hline DZIECKO I & $38,0(42)^{\star}$ & 52,5 & 38,1 \\
\hline DZIECKO II & $57,5(78)^{\star}$ & 65,0 & 13,0 \\
\hline DZIECKO III & $37,5(63)^{\star}$ & 45,0 & 20,0 \\
\hline
\end{tabular}

* Wartości normatywne odpowiednie dla wieku każdego z dzieci (wg [Bellis, 2003]).
Tabela 4. Wyniki testu różnicowania wzorców długości (ang. duration pattern test - DPT) uzyskane u każdego dzieci przed rozpoczęciem terapii Neurofeedback oraz po jej zakończeniu. W tabeli umieszczono również procentową wartość zmiany wyniku po zakończeniu terapii

\begin{tabular}{cccc}
\hline DPT & Przed terapią & Po terapi & \% zmiany \\
\hline DZIECKO I & $35,0(40)^{*}$ & 47,5 & 35,7 \\
\hline DZIECKO II & $65,0(70)^{*}$ & 72,5 & 11,5 \\
\hline DZIECKO III & $22,5(54)^{*}$ & 32,5 & 44,4 \\
\hline * Wartości normatywne odpowiednie dla wieku każdego \\
z dzieci (wg [Bellis, 2003]).
\end{tabular}


Tabela 5. Wyniki testu cyfrowego testu rozdzielno-usznego (ang. dichotic digits test - DDT) uzyskane u każdego dzieci przed rozpoczęciem terapii Neurofeedback oraz po jej zakończeniu. W tabeli umieszczono także procentową wartość zmiany wyniku po zakończeniu terapii

\begin{tabular}{ccccccc}
\hline \multirow{2}{*}{ DDT } & \multicolumn{3}{c}{ Ucho prawe } & \multicolumn{3}{c}{ Ucho lewe } \\
\cline { 2 - 7 } & przed terapią & po terapi & \% zmiany & przed terapią & po terapii & \% zmiany \\
\hline DZIECKO I & $72,5(75)^{*}$ & 82,5 & 13,7 & $52,5(65)$ & 55,5 & 5,7 \\
\hline DZIECKO II & $84,0(85)^{*}$ & 90,0 & 7,1 & $75,0(78)$ & 90,0 & 20,0 \\
\hline DZIECKO III & $70,0(80)^{*}$ & 67,5 & $-3,5$ & $60,2(75)$ & 70,5 & 17,1 \\
\hline
\end{tabular}

*Wartości normatywne odpowiednie dla wieku każdego z dzieci (wg [Bellis, 2003]).

poznawczego a konkretnie różne aspekty procesu uwagi oraz pamięć operacyjną przed i po zastosowanej terapii. Tabela 2 przedstawia zestawienie zmian najważniejszych parametrów $\mathrm{w}$ wybranych próbach $\mathrm{z}$ baterii testów TAP u każdego $\mathrm{z}$ trenowanych dzieci.

Najwięcej korzystnych zmian po terapii zaobserwowano u DZIECKA I. W teście Divided Attention, Flexibility, oraz Working Memory poprawie uległy wszystkie z testowanych parametrów. U tego samego dziecka W teście Go-Nogo, skrócił się czas reakcji jak również zmniejszyła liczba popełnionych błędów. Korzystne zmiany zaobserwowano również w badającym czujność teście Alertness, w którym również skróciły się czasy reakcji, zmniejszyła wariancja odpowiedzi oraz polepszył indeks fazowy ${ }^{2}$. Co ciekawe, zupełnie odwrotną tendencję zaobserwowano w teście Cross-modal Integration gdzie parametry nie poprawiły się lecz uległy niewielkiemu pogorszeniu (większa liczba błędów i ominięć) [Zimmermann, Fimm 1997].

Równie korzystne (choć w mniejszej liczbie testów) zmiany parametrów po zakończeniu terapii odnotowano również u DZIECKA II. W teście Divided Attention poprawie uległa liczba ominięć, która była mniejsza zarówno dla bodźców słuchowych jak i wzrokowych. Także w teście Flexibility skrócił się znacznie czas reakcji oraz poprawiła się stabilność odpowiedzi. Liczba popełnionych błędów pozostała na tym samym poziomie. U DZIECKA II poprawie po terapii uległy również wyniki w testach Working Memory i Go-Nogo. W pierwszym z nich zmniejszyła się liczba ominięć, w drugim zaś zmniejszyła się liczba błędów i skróciły czasy reakcji. W teście Alertness poprawił się indeks fazowy, w próbach z dźwiękiem i bez dźwięku wydłużyły się natomiast nieznacznie czasy reakcji. Z kolei w teście Cross-modal Integration odnotowano brak wpływu na wyniki.

Korzystne zmiany po zakończeniu terapii Neurofeedback zauważono także u DZIECKA III. W testach Divided Attention i Go-Nogo zmniejszyła się liczba popełnianych błędów, natomiast w testach Working Memory i Cross- modal Integration liczba ominięć. W teście Flexibility poprawiła się stabilność odpowiedzi (SD dla czasu reakcji). U DZIECKA III zaobserwowano również kilka niekorzystnych zmian. W teście Flexibility zwiększyła się liczba błędów i wydłużył czas reakcji a w teście Go-Nogo oprócz dłuższych czasów reakcji zwiększyła się również niestabilność odpowiedzi. Niekorzystne zmiany odnotowano również w teście Alertness. W próbie tej wydłużyły się zarówno czasy reakcji (próby z dźwiękiem i bez dźwięku) jak również pogorszyła stabilność odpowiedzi (większe SD dla RT) i spadło wzbudzenie (ujemny indeks fazowy).

Przetwarzanie informacji akustycznej w wyższych ośrodkach słuchowych po zakończeniu terapii Neurofeedback oceniano na podstawie testów behawioralnych. Wyniki poszczególnych testów przed i po zakończeniu treningów Neurofeedback prezentują odpowiednio Tabele 3-5. Zestawienie wyników testów w graficznej formie prezentuje Rycinie 2.

Analiza uzyskanych wyników pokazuje, że lepsze wyniki w teście FPT jak i DPT po zakończeniu terapii zaobserwowano u każdego $\mathrm{z}$ trenowanych dzieci. W teście FPT największą poprawę wyniku po terapii uzyskano u DZIECKA I (prawie 40\%). Wynik tego samego testu u DZIECKA II i III zmienił się natomiast odpowiednio o 20 i $13 \%$ (Tabela 3). Jeżeli chodzi o test DPT to największą poprawę $\mathrm{w}$ tym teście po zakończeniu terapii odnotowano u DZIECKA III. Po terapii, lecz w trochę mniejszym stopniu, poprawił się także wynik testu DZIECKA I. Najmniejszą zmianę w teście różnicowania wzorców długości dźwięków odnotowano natomiast u DZIECKA II (Tabela 4).

Oprócz poprawy wyników testów FPT i DPT korzystne efekty po terapii zaobserwowano również w cyfrowym teście rozdzielno-usznego słyszenia - DDT. U DZIECKA I wynik testu DDT uległ poprawie zarówno w lewym jak i prawym uchu przy czym w uchu prawym poprawa była dużo bardziej widoczna (13,7\%) niż w uchu lewym (5,7\%). U DZIECKA II zaobserwowano bardzo podobny procent korzystnych zmian,z tym, że efekt ten był odwrotny w stosunku do ucha. Po zakończeniu terapii wyniki w odniesieniu do ucha lewego były znacznie lepsze (20\%) niż do ucha prawego $(5,8 \%)$. Poprawę w teście DDT w uchu lewym po terapii odnotowano również u DZIECKA III. Wynik w uchu prawym u tego dziecka był gorszy po zakończeniu terapii (Tabela 5).

\section{Dyskusja}

W prezentowanej pracy terapii Neurofeedback poddano dzieci $z$ problemami w zakresie przetwarzania informacji akustycznej w wyższych ośrodkach słuchowych. Wszystkie z dzieci miały prawidłowe wyniki testów oceniających słuch obwodowy (Tabela 1), uzyskując przy tym

\footnotetext{
2. indeks fazowy $=\frac{\text { mediana RT w próbach bez dźwięku }- \text { mediana RT w próbach dźwięku }}{\text { mediana RT dla wszystkich prób (z dźwiękiem i bez dźwięku) }}$
} 

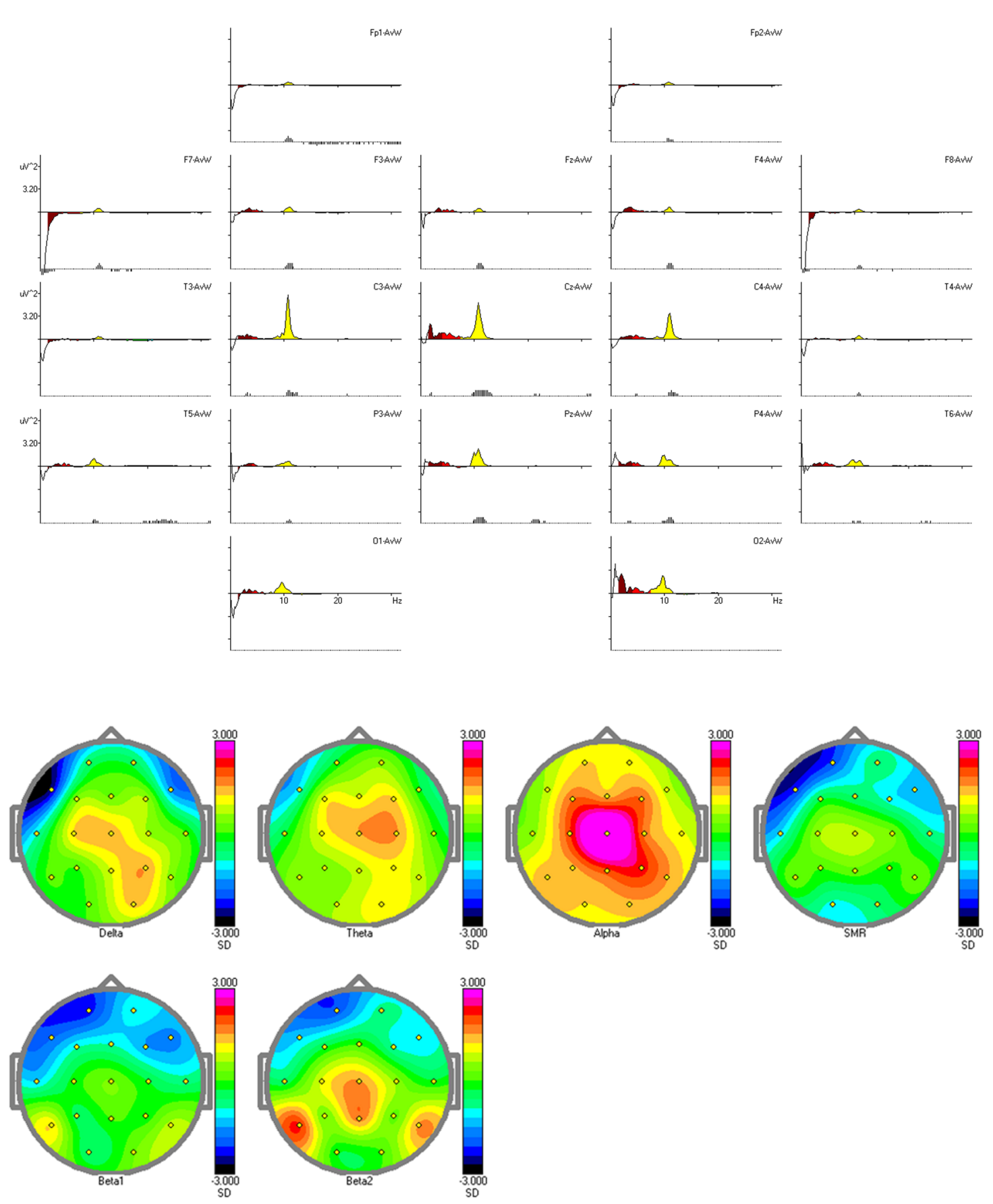

Rycina 1. Widma amplitudy różnicowej obliczonej dla sygnałów zarejestrowanych z 19 kanałów u jednego z badanych dzieci (DZIECKO I). Widma te powstały poprzez porównanie wartości amplitudy poszczególnych pasm częstotliwości w sygnale EEG zarejestrowanym u badanego dziecka z wartościami amplitudy sygnałów dzieci w podobnym zakresie wieku znajdujących się w bazie normatywnej HBI. Pod widmami umieszczono mapy (2D) obrazujące rozkład przestrzenny amplitudy różnicowej i odchylenie standardowe wartości amplitud pacjenta od normy w rozdziale na standardowe pasma częstotliwości. Intensywność koloru czarnego zależy od wartości standardowego odchylenia

nieprawidłowe wyniki w testach wyższych funkcji słuchowych (Tabele 3-5). U każdego z dzieci możliwe było więc stwierdzenie ośrodkowych zaburzeń słuchu [ASHA, 1996]. Każde z dzieci oprócz problemów ze słuchem charakteryzowało się również towarzyszącymi tym dysfunkcjom zaburzeniami koncentracji uwagi i/lub problemami z pamięcią operacyjną. Potwierdziły to wyniki poszczególnych prób oceniających różne aspekty uwagi i pamięci zawartych w komputerowej baterii testów TAP (Tabela 2). Na problemy w zakresie procesów uwagowych wskazywały też wyniki analiz ilościowych EEG, które przeprowadzono na sygnałach bioelektrycznych zarejestrowanych u wszystkich dzieci. Wynikało z nich, że u każdego z dzieci dochodzi do nadmiernej ekspresji wolnych fal mózgowych. 
Tabela 6. Wartości oraz poziom istotności p różnic amplitudy poszczególnych pasm częstotliwości w sygnale EEG zarejestrowanym u jednego z badanych dzieci (DZIECKO I) oraz amplitudy tych samych pasm obliczonych z sygnatów dzieci w podobnym zakresie wieku zawartych w bazie normatywnej HBI

\begin{tabular}{|c|c|c|c|c|c|c|}
\hline & $\begin{array}{c}\text { Delta } \\
(1-4 \mathrm{~Hz})\end{array}$ & $\begin{array}{l}\text { Theta } \\
(4-8 \mathrm{~Hz})\end{array}$ & $\begin{array}{c}\text { Alpha } \\
\text { (8-12 Hz) }\end{array}$ & $\begin{array}{c}\text { SMR } \\
(12-15 \mathrm{~Hz})\end{array}$ & $\begin{array}{c}\text { Beta1 } \\
(15-20 \mathrm{~Hz})\end{array}$ & $\begin{array}{c}\text { Beta2 } \\
(20-34 \mathrm{~Hz})\end{array}$ \\
\hline Fp1-AvW & $-3,52 \quad p<0,538$ & $-0,64 p<0,813$ & $1,54 p<0,230$ & $-0,28 p<0,044$ & $-1,31 \quad p<0,025$ & $-3,25 p<0,047$ \\
\hline Fp2-AvW & $-3,82 p<0,630$ & $0,50 p<0,648$ & $1,64 p<0,289$ & $-0,22 p<0,514$ & $-1,13 p<0,336$ & $-2,88 p<0,429$ \\
\hline F7-AvW & $-20,71 p<0,011$ & $-2,88 p<0,279$ & $1,08 p<0,482$ & $-0,42 p<0,029$ & $-1,49 \quad p<0,065$ & $-2,75 p<0,207$ \\
\hline F3-AvW & $0,86 p<0,735$ & $2,09 p<0,342$ & $3,83 p<0,081$ & $-0,17 p<0,664$ & $-1,07 \quad p<0,326$ & $-1,29 p<0,698$ \\
\hline Fz-AvW & $0,55 p<0,794$ & $2,26 p<0,383$ & $2,41 p<0,160$ & $-0,16 p<0,533$ & $-0,44 \quad p<0,358$ & $-0,12 p<0,963$ \\
\hline F4-AvW & $2,09 p<0,592$ & $2,87 p<0,234$ & $3,78 p<0,075$ & $-0,34 p<0,285$ & $-1,63 \quad p<0,138$ & $-2,62 p<0,362$ \\
\hline F8-AvW & $-12,48 \quad p<0,116$ & $-0,83 p<0,813$ & 457 & $-0,31 p<0,163$ & $-1,19 \quad p<0,110$ & $-2,10 p<0,271$ \\
\hline T3-AvW & $-4,84 p<0,346$ & $-1,20 p<0,747$ & $0,75 p<0,624$ & $-0,62 p<0,252$ & $-2,97 \quad p<0,236$ & $-3,35 p<0,624$ \\
\hline C3-AvW & $4,82 p<0,228$ & $2,41 p<0,329$ & $24,38 p<0,040$ & $0,07 p<0,599$ & $-0,31 \quad p<0,863$ & $0,44 p<0,351$ \\
\hline Cz-AvW & $9,44 p<0,178$ & $9,11 p<0,138$ & $26,83 p<0,000$ & $0,12 p<0,454$ & $0,06 \quad p<0,746$ & $0,54 p<0,126$ \\
\hline C4-AvW & $1,78 p<0,560$ & $4,18 p<0,126$ & $17,90 p<0,084$ & $0,02 p<0,739$ & $-0,49 \quad p<0,764$ & $0,17 p<0,623$ \\
\hline T4-AvW & $-0,60 \quad p<0,981$ & $-0,30 p<0,981$ & $2,05 p<0,336$ & $-0,35 p<0,444$ & $-1,63 \quad p<0,478$ & $-2,11 p<0,804$ \\
\hline T5-AvW & $-0,75 p<0,945$ & $1,43 p<0,610$ & $6,49 p<0,155$ & $-0,12 p<0,825$ & $1,35 p<0,253$ & $2,50 p<0,074$ \\
\hline P3-AvW & $-0,77 p<0,993$ & $0,64 p<0,684$ & 0,170 & $-0,13 p<0,993$ & $-0,57 \quad p<0,689$ & $<0,707$ \\
\hline Pz-AvW & $5,83 p<0,363$ & $2,54 p<0,469$ & $15,63 p<0,046$ & $-0,05 p<0,844$ & $-0,24 \quad p<0,986$ & $0,46 p<0,098$ \\
\hline P4-AvW & $6,79 p<0,146$ & $2,93 p<0,285$ & $11,41 p<0,025$ & $-0,17 p<0,898$ & $-0,44 \quad p<0,891$ & $-0,02 p<0,819$ \\
\hline T6-AvW & $1,76 p<0,677$ & $2,77 p<0,460$ & $8,14 p<0,127$ & $-0,09 p<0,831$ & $0,62 p<0,465$ & $1,61 p<0,119$ \\
\hline O1-AvW & $-2,18 \quad p<0,974$ & $2,15 p<0,552$ & $9,45 p<0,231$ & $-0,84 p<0,325$ & $-0,86 \quad p<0,593$ & $-0,32 p<0,831$ \\
\hline O2-AvW & $18,81 p<0,202$ & $6,45 p<0,256$ & $16,11 p<0,164$ & $-0,83 p<0,553$ & $-0,03 \quad p<0,785$ & $-0,19 p<0,987$ \\
\hline
\end{tabular}

Tabela 7. Wartości współczynników opisujących wzajemne relacje fal wolnych do szybkich uzyskane w analizach ilościowych u poszczególnych dzieci. Obliczenia współczynników dokonano analizując sygnały zarejestrowane z odprowadzenia centralnego (Cz) (wg międzynarodowego standardu 10/20; [Jasper, 1958])

\begin{tabular}{ccccccc}
\hline \multirow{2}{*}{ Współczynnik } & \multicolumn{2}{c}{ DZIECKO I } & \multicolumn{2}{c}{ DZIECKO II } & \multicolumn{2}{c}{ DZIECKO III } \\
\cline { 2 - 7 } & przed terapią & po terapii & przed terapią & po terapii & przed terapią & po terapii \\
\hline Delta/SMR & 4,54 & 4,06 & 4,15 & 3,46 & 3,85 & 3,74 \\
\hline Delta/Beta1 & 5,33 & 4,57 & 3,99 & 3,36 & 4,44 & 3,41 \\
\hline Delta/Beta2 & 4,23 & 3,65 & 3,69 & 3,60 & 4,06 & 3,69 \\
\hline Theta/SMR & 3,64 & 3,46 & 3,53 & 3,09 & 3,49 & 3,40 \\
\hline Theta/Beta1 & 4,85 & 4,31 & 3,66 & 3,40 & 4,57 & 3,48 \\
\hline Theta/Beta2 & 3,38 & 3,10 & 2,95 & 3,21 & 4,06 & 3,33 \\
\hline Alfa/SMR & 3,29 & 3,55 & 2,93 & 2,95 & 2,24 & 2,47 \\
\hline Alfa/Beta1 & 5,00 & 3,98 & 2,81 & 2,75 & 2,34 & 2,25 \\
\hline Alfa/Beta2 & 2,44 & 3,18 & 2,89 & 3,07 & 2,13 & 2,42 \\
\hline \hline
\end{tabular}



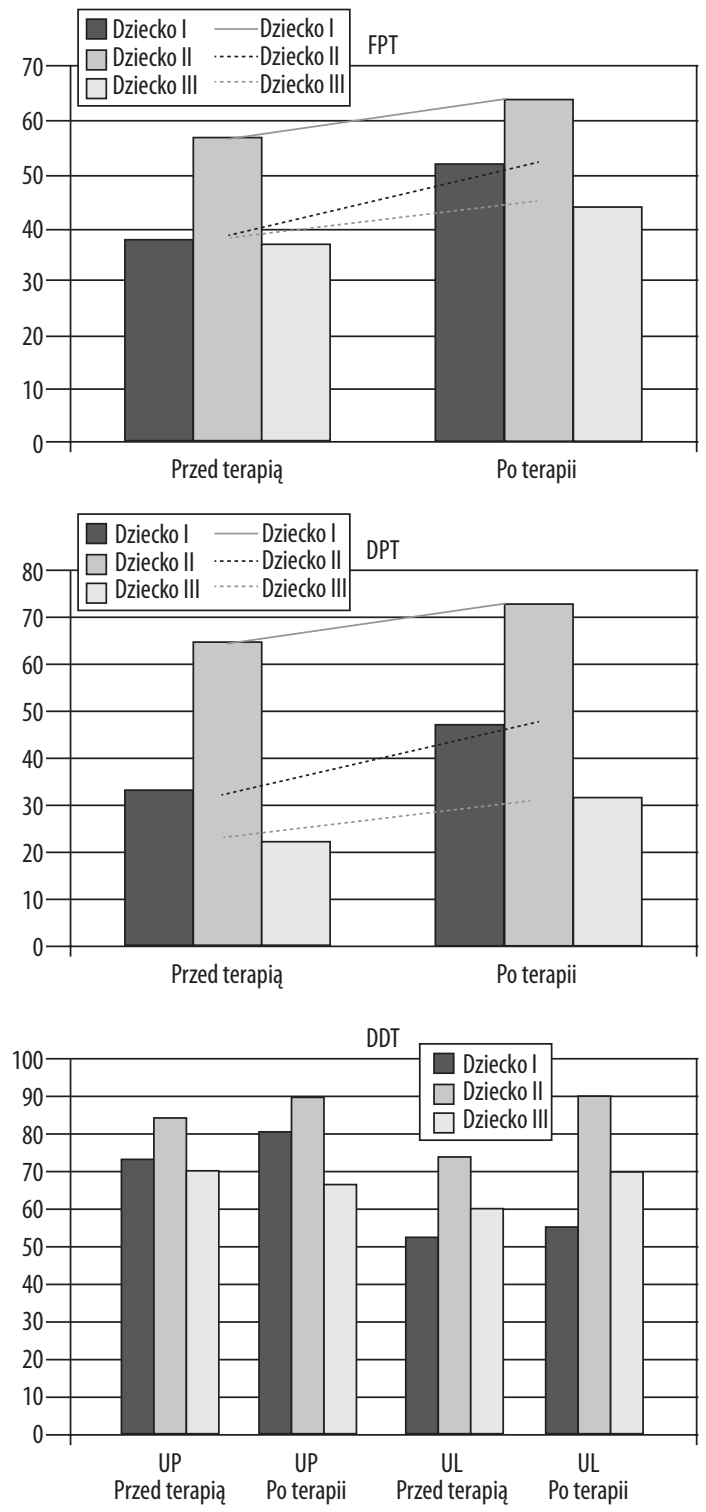

Rycina 2. Porównanie wyników testów wyższych funkcji słuchowych: testu różnicowania wzorców częstotliwości (FPT), testu różnicowania wzorców długości (DPT) oraz cyfrowego testu rozdzielno-usznego styszenia (DDT) przed i po terapii Neurofeedback. Na wykresach przedstawiających wyniki testów FPF i DPT liniami przerywanymi oznaczono linie trendów opisujące kierunek zmiany wyników po terapii

Zawyżony udział dotyczył przede wszystkim fal z zakresu Alfa (8-12 Hz) jak również choć w mniejszym stopniu fal Theta $(4-8 \mathrm{~Hz})$ oraz Delta (1-4 Hz) (Rycina 1, Tabela 6). Nadmiernie wyrażonej czynności wolnej towarzyszyła zaniżona we wszystkich zakresach częstotliwości czynność szybka. Oba efekty obserwowano przede wszystkim w rejonach centralno-ciemieniowych oraz czołowych.

Jak pokazują dane literaturowe, opisane powyżej wzorce aktywacji mózgu są bardzo charakterystyczne dla dzieci mających problemy z uwagą czy pamięcią operacyjną. Nadmierną ekspresję fal Alfa w obszarach centralno-ciemieniowych obserwowano wielokrotnie u dzieci z zespołem deficytu uwagi (ang. Attention Deficit Disorder - ADD) czy też z zespołem nadpobudliwości psychoruchowej (ang. Attention Deficit Hyperactivity Disorder - ADHD) (podtyp uwagowy). Sądzi się, że aktywność ta pochodzi z obszarów kory, które mogą odgrywać kluczową rolę w procesach uwagowych. Rytm Alfa jest, jak wiadomo, negatywnie skorelowany z metaboliczną aktywnością kory mózgowej [Kropotov 2009]. Generowany w nadmiarze w obszarach mózgu związanych z procesem uwagi, może więc wskazywać, że rejony te działają mniej efektywnie i gorzej realizują swoje funkcje. Podobne funkcjonalne znaczenie przypisuje się również rytmowi Theta. Zawyżona czynność Theta w rejonach czołowych była również wielokrotnie obserwowana u dzieci z ADD [Chabot, Serfontein, 1996]. Jej nadmierna ekspresja w przednich okolicach mózgu świadczy najprawdopodobniej o niedojrzałości lub niedostatecznej aktywacji płatów czołowych [Kropotov 2009]. U dzieci z ADHD zawyżonej czynności Theta w przednich częściach mózgu bardzo często towarzyszy zbyt słabo wyrażona czynność szybka - Beta. Zwiększenie fal z tego zakresu w sytuacjach koncentracji uwagi lub jej ogniskowania na jakimś bodźcu lub zadaniu znane jest od bardzo dawna [Linden, Habib, Rafojevic 1996]. Niedostateczna ekspresja fal Beta w rejonach czołowych może więc świadczyć o spowolnionym przetwarzaniu informacji lub nieprawidłowym funkcjonowaniu związanych $\mathrm{z}$ uwagą i/lub pamięcią operacyjną rejonów mózgu [Cook i wsp. 1999].

W terapii różnego rodzaju zaburzeń funkcji poznawczych, poprzez modyfikację fal mózgowych, od wielu lat skutecznie stosowana jest technika Neurofeedback [Coben, Evans 2011]. Wielokrotnie udowodniono, że poprzez zmianę nieprawidłowej ekspresji fal generowanych w okolicach związanych z procesami uwagi czy pamięci, można uzyskać znaczącą poprawę koncentracji uwagi czy zapamiętywania [Gruzelier i wsp. 2006]. W prezentowanej pracy metodę Neurofeedback postanowiono wykorzystać w terapii dzieci z ośrodkowymi zaburzeniami słuchu oraz wykazującymi jednocześnie deficyty uwagi i pamięci operacyjnej. Biorąc pod uwagę dane wskazujące, że nieprawidłowe funkcjonowanie procesów poznawczych poprzez oddziaływania top-down, może negatywnie wpływać na przetwarzanie informacji akustycznej założono że usprawniając za pomocą Neurofeedback procesy uwagowe czy pamięciowe, ich poprawa powinna korzystnie wpłynąć także na realizację funkcji słuchowych [Moore, 2008].

Analiza udziału procentowego poszczególnych fal mózgowych w zarejestrowanych sygnałach EEG oraz współczynników wyrażających relacje fal w stosunku do siebie pokazała, że zastosowany trening Neurofeedback spowodował korzystne zmiany w aktywacji mózgu. Dotyczyły one zarówno wolnej czynności bioelektrycznej mózgu jak i czynności szybkiej. Po treningach doszło przede wszystkim do obniżenia najwolniejszych fal w zakresie pasma Delta oraz Theta. Wskazują na to porównania przed i po terapii wartości procentowego udziału poszczególnych fal w sygnale EEG (Tabela 8) jak i przede wszystkim zmiana po terapii wartości współczynników wyrażających relacje fal Delta oraz Theta $\mathrm{z}$ falami szybkimi (Tabela 7). Celem treningów Neurofeedback było również obniżenie nadmiernie wyrażonej ekspresji fal w paśmie Alfa. Jak wynika $\mathrm{z}$ analizy porównawczej czynności ta poddała się w niewielkim 
Tabela 8. Udział procentowy poszczególnych zakresów fal mózgowych obliczony w analizie ilościowej EEG wykonanej na sygnałach zarejestrowanych u każdego z dzieci w punkcie centralnym głowy $(\mathrm{Cz})$ przed rozpoczęciem terapii Neurofeedback oraz po jej zakończeniu

\begin{tabular}{ccccccc}
\hline \multirow{2}{*}{ Pasmo } & \multicolumn{2}{c}{ DZIECKO I } & \multicolumn{2}{c}{ DZIECKO II } & \multicolumn{2}{c}{ DZIECKO III } \\
\cline { 2 - 7 } & przed terapią & po terapii & przed terapią & po terapii & przed terapią & po terapii \\
\hline Delta & 33,08 & $\mathbf{2 8 , 8 8}$ & 30,66 & $\mathbf{2 7 , 7 3}$ & 31,67 & $\mathbf{2 9 , 5 6}$ \\
\hline Theta & 26,50 & $\mathbf{2 4 , 5 2}$ & 24,50 & 24,73 & 28,52 & $\mathbf{2 6 , 6 1}$ \\
\hline Alfa & 19,14 & 20,23 & 21,53 & 23,62 & 16,70 & 18,37 \\
\hline SMR & 7,29 & 7,10 & 7,36 & $\mathbf{8 , 0 1}$ & 8,18 & 7,83 \\
\hline Beta 1 & 6,17 & $\mathbf{6 , 3 4}$ & 7,66 & $\mathbf{8 , 2 1}$ & 7,14 & $\mathbf{8 , 6 1}$ \\
\hline Beta 2 & 7,81 & 7,74 & 8,29 & 7,70 & 7,69 & 7,02 \\
\hline
\end{tabular}

Czcionką pogrubioną oznaczono wartości procentowe w sygnale EEG, które zmieniły się w kierunku zgodnym z celem prowadzonej terapii.

stopniu korzystnej modyfikacji. W trakcie terapii usiłowano również zwiększyć udział fal szybkich SMR oraz Beta1. $\mathrm{Na}$ podstawie analizy parametrów ilościowych widać, że u wszystkich dzieci cel ten został osiągnięty zwłaszcza jeżeli chodzi o fale w zakresie pasma Beta1. Świadczyć o tym może zarówno udział procentowy fal Beta1, które odnotowano po terapii jak i obniżenie współczynnika Alfa/Beta1. Trzeba przy tym zaznaczyć, że obniżenie współczynnika Alfa/Beta1 nie było najprawdopodobniej efektem spadku fal Alfa gdyż, udział procentowy oraz relacje tego zakresu fal z innymi falami szybkimi pozostają mniej więcej tym samym poziomie przed i po terapii. Jest co prawda widoczna niewielka tendencja do wzrostu po terapii współczynnika Alfa/Beta2. Wynika ona jednak ze zmniejszenia czynności Beta2, której obniżenie może wiązać się z większym poziomem relaksu i odprężeniem pod koniec terapii.

Przedstawione powyżej zmiany czynności bioelektrycznej mózgu, widoczne w analizach ilościowych QEEG po zakończeniu terapii, miały swoje odzwierciedlenie w wynikach komputerowych testów uwagi i pamięci (TAP). Najwięcej korzystnych zmian odnotowano w testach Divided Attention, Flexibility oraz Working Memory. W pierwszym $\mathrm{z}$ testów poprawa wyników widoczna była u każdego z trenowanych dzieci (u DZIECKA I i II prawie we wszystkich ocenianych parametrach testów). U dwojga dzieci, poprawę większości parametrów odnotowano również w pozostałych wymienionych testach. Każdy z testów pozwalał ocenić odpowiednio: podzielność, przerzutność uwagi oraz pamięć operacyjną [Zimmermann, Fimm 1997]. Poprawa w wynikach wymienionych testów może więc świadczyć o poprawie tych funkcji po zakończeniu terapii. Korzystne zmiany, choć może nie obejmujące wszystkich parametrów, odnotowano również w testach Alertness oraz Go-Nogo. W pierwszym z testów, parametrem w stosunku do którego odnotowano najkorzystniejszą zmianę był indeks fazowy, w drugim $\mathrm{z}$ testów poprawie uległa przede wszystkim szybkość odpowiedzi oraz mniejsza była liczba popełnianych błędów. Test Alertness to próba, w której testowana jest przede wszystkim czujność badanej osoby. Jednym $\mathrm{z}$ ocenianych parametrów tego testu jest tzw. indeks fazowy, który wyliczany jest po zakończeniu testu Alertness. Pozwala on ocenić jak zmienia się poziom czujności badanej osoby pod wpływem przychodzącego nagle bodźca
[Zimmermann, Fimm 1997]. Bardziej dodatnie wartości tego parametru uzyskiwane przez dzieci po zakończeniu terapii mogą świadczyć, iż po treningach Neurofeedback dzieci były bardziej czujne i szybciej wzbudzały się po przyjściu bodźca czyli były w stanie szybciej „dostrzec” docierające do nich informacje. Test Go-Nogo to z kolei test, który został zaprojektowany by badać między innymi selektywność uwagi oraz poprawność podejmowanych decyzji [Zimmermann, Fimm 1997]. Uzyskane wyniki mogą więc sugerować, że po treningu również te funkcje były lepiej realizowane. Stosunkowo mniejszą poprawę zauważono natomiast $\mathrm{w}$ teście ewaluującym integrację międzymodalną (Cross-modal Integration) [Zimmermann, Fimm 1997]. Poprawę wyników odnotowano jedynie u DZIECKA III. Trzeba jednak zauważyć, że w omawianym teście dziecko uzyskało liczbę ominięć mniejszą zaledwie o jeden. Patrząc na wyniki wszystkich dzieci w tym teście można więc stwierdzić, iż zastosowany trening najmniej korzystniej wpłynął na funkcję integracji wzrokowo-słuchowej. Trudno również wytłumaczyć pogorszenie się wyników testu Cross-modal Integration u DZIECKA I, u którego największą poprawę odnotowano we wszystkich pozostałych testach uwagi. Być może gorszy wynik u tego dziecka wynikał ze zmęczenia. U DZIECKA I omawiany test wykonywany był bowiem jako ostatni w całej baterii 7 testów.

Poza oceną funkcji poznawczych, zasadniczym celem prezentowanej pracy była jednak ocena wpływu zastosowanego treningu na funkcje słuchowe. Przed rozpoczęciem terapii wyniki testów wyższych funkcji słuchowych wszystkich poddanych terapii dzieci znajdowały się poniżej normy (Tabele 3-5) [Bellis, 2003]. Po zakończeniu terapii uległy one poprawie i w większości przypadków osiągnęły wartość normatywną. Oceniając procent zmiany wyniku w przypadku każdego testu wydaje się, że po zakończeniu terapii największym zmianom uległy wyniki testów FPT oraz DPT. U każdego z dzieci uzyskano mniejszą lub większą poprawę w zarówno w jednej jak i drugiej z prób. Testy FPT i DPT jak sam nazwa mówi pozwalają ocenić funkcje słuchowe takie jak różnicowanie częstotliwości czy też długości odbieranych dźwięków. W obu testach rozpoznawany i powtarzany jest także wzorzec dźwięków. Wykonanie testów daje więc też informację o stanie funkcjonowania pamięci operacyjnej [Bellis, 2003]. Poprawa po 
treningach wyników w obu testach świadczy zaś o poprawie funkcji, które za ich pomocą badano.

Po zakończeniu terapii Neurofeedback, oprócz testów FPT i DPT, procentową poprawę wyników, choć nieco mniejszą, zaobserwowano również $\mathrm{w}$ teście rozdzielno-usznego słyszenia - DDT. Zarówno u DZIECKA I jak i DZIECKA II lepsze wyniki po cyklu treningowym uzyskano zarówno dla lewego jak i prawego ucha. Zwraca jednak uwagę fakt, iż u każdego z wymienionych dzieci, wyniki poprawiały się $\mathrm{w}$ każdym $\mathrm{z}$ uszu w odwrotny sposób: u DZIECKA I lepsza poprawa w prawym, zaś u DZIECKA II w lewym uchu. Lepsze wyniki po zakończeniu terapii obserwowano również u DZIECKA III. Poprawa wyników była jednak widoczna wyłącznie dla lewego ucha. Wynik testu DDT u DZIECKA III w uchu prawym po terapii uległ natomiast niewielkiemu pogorszeniu. Na podstawie testu rozdzielno-usznego słyszenia można oceniać specjalizację półkulową oraz transmisję między dwoma półkulami mózgu [Iliadou i wsp. 2010]. Jeżeli jest ona prawidłowa i półkulą dominującą w zakresie procesów językowych jest lewa półkula powoduje to, iż sygnał z prawego (kontralateralnego) ucha przetwarzany jest bardziej, natomiast $\mathrm{z}$ ucha lewego (ipsilateralnego) niedominującego mniej efektywnie. Dzieje się tak ponieważ ipsilateralne drogi słuchowe są wytłumiane i sygnał musi najpierw trafić do prawej półkuli by następnie przez spoidło wielkie dotrzeć do lewej właściwej dla odbioru informacji akustycznej półkuli [Zaidel 1983]. W przypadku badanych dzieci wyniki uzyskane w teście DDT przed rozpoczęciem terapii wskazywały na prawidłową lateralizację językową każdego z nich (Tabela 5). Procentowa zmiana wyników pod wpływem terapii wskazywałaby, że $\mathrm{u}$ dwojga dzieci informacja $\mathrm{z}$ niedominującego ucha lewego przetwarzana była znacznie efektywniej po treningach. Na tym etapie badań na pewno trudno wytłumaczyć uzyskany wynik. Można jednak spekulować, że był to na przykład efekt usprawnienia po treningach procesów transmisji między półkulowej zależnych od procesu uwagi. Wydaje się, że ta hipoteza może nie być pozbawiona sensu zwłaszcza jeśli weźmie się pod uwagę doniesienia wskazujące na istotną rolę spoidła wielkiego, pozostającego pod kontrolą procesów uwagowych top-down, i wpływającego na wzmocnienie transmisji informacji ze słabszego lewego ucha. [Westerhausen, Hugdahl, 2008].

\section{Wnioski}

Wyniki uzyskane w prezentowanej pracy sugerują iż zastosowanie treningu Neurofeedback u dzieci z ośrodkowymi zaburzeniami słuchu może mieć korzystny wpływ zarówno na realizację funkcji poznawczych (uwagi, pamięci operacyjnej) jak również na poprawę funkcji słuchowych. By potwierdzić przedstawione powyżej stwierdzenie konieczne są jednak poparte analizą statystyczną dalsze badania na większej grupie dzieci.

\section{Piśmiennictwo:}

1. American Speech-Language-Hearing Association Task Force on Central Auditory Processing Consensus Development: Current status of research and implications for clinical practice. Am J Audiol, 1996; 5(2): 41-54

2. American Speech-Language-Hearing Association: (Central) Auditory Processing Disorders [Technical Report], 2005. Available from www.asha.org/policy

3. Bellis T.J.: Assessment and management of central auditory processing disorders in the educational setting: From science to practice, New York: Delmar Thomson Learning, 2003

4. Chabot R.J., Serfontein G.: Quantitative electroencephalographic profiles of children with attention deficit disorder. Biol Psychiatry, 1996; 40(10): 951-63

5. Coben R., Evans J.R.: Neurofeedback and Neuromodulation Techniques and Applications. Amsterdam: Elsevier/Academic Press, 2011

6. Cook I.A., Leuchter A.F., Witte E i wsp.: Neurophysiologic predictors of treatment response to fluoxetine in major depression. Psychiatry Res, 1999; 85: 263-73

7. Ferre J.M.: Behavioral Therapeutic Approaches for Central Auditory Problems. (W:) Katz J. (red.) Handbook of Clinical Audiology, $6^{\text {th }}$ edition. Philadelphia: Lippincott Williams and Wilkins, 2009; 525-31

8. Gruzelier J., Egner T., Vernon D.: Validating the efficacy of neurofeedback for optimizing performance. Prog Brain Res, 2006; 159: 421-31

9. Masquelier M.P.: Management of auditory processing disorders. Acta Otorhinolaryngol Belg, 2003; 57(4): 301-10

10. Musiek G.D., Chermak G.D.: Handbook of (central) auditory processing disorder, San Diego: Plural Publishing, 2007
11. Linden M., Habib T., Radojevic V.: A controlled study of the effects of EEG biofeedback on cognition and behavior of children with attention deficit disorder and learning disabilities. Biofeedback Self Regul, 1996; 21(1): 35-49

12. Iliadou V., Kaprinis S., Kandylis D., Kaprinis G.S.: Hemispheric laterality assessment with dichotic digits testing in dyslexia and auditory processing disorder. Int J Audiol, 2010; 49(3): $247-52$

13. Jasper H.H.: The ten-twenty electrode system of the international federation. Electroencephalography and Clinical Neurophysiology, 1958; 10: 371-558

14. Medwetsky L.: Central auditory processing. (W:) Katz J. (red.) Handbook of Clinical Audiology, 6th edition. Philadelphia: Lippincott Williams and Wilkins, 2009; 495-509

15. Moore D.R., Ferguson M.A., Halliday L.F., Riley A.: Frequency discrimination in children: perception, learning and attention. Hear Res, 2008; 238, 147-54

16. Kropotov J.: Quantitative EEG, Event-related potentials and Neurotherapy. London: Elsevier/Academic Press, 2009

17. Westerhausen R., Hugdahl K.: The corpus callosum in dichotic listening studies of hemispheric asymmetry: A review of clinical and experimental evidence. Neurosci Biobehav Rev, 2008; 32: 1044-54

18. Zaidel E.: Disconnection syndrome as a model for laterality effects in the normal brain. (W:) Hellige J.B. (red.). Cerebral Hemisphere Asymmetry: Method, Theory, and Application. New York: Praeger, 1983; 95-151

19. Zimmermann P., Fimm B.: Test for Attention Performance (TAP). Würselen: Psytest, 1997 